\title{
CIDADE E AS NARRATIVAS DE SOLIDARIEDADE
}

\section{APRESENTAÇÃO}

As cidades configuram o contexto que abriga a maior parte da população no mundo contemporâneo. Sua dinâmica apoiada em estruturas institucionais e organizacionais complexas, regulam as formas da vida social. Determinações de vida social estas, recheadas de paradoxos e contradições próprias dos matizes do capitalismo que orientam as relações políticas e econômicas das populações urbanas.

A sociedade moderna, urbanizada e industrializada, desde cedo foi analisada por intelectuais da modernidade. A teoria da forma de Georg Simmel (1858-1918) nos ensina, entre outros, sobre as formas de sociação, referindo-se sobre os processos de dominaçãosubordinação, sobre a condição do conflito, como a competição, e outras formas puras de sociação, no seu ponto de vista, como círculos sociais, sociedade secreta, pobreza, referindose as noções de proximidade e afastamento, de distância social, isolamento e vizinhança. Mas estas referências espaciais apenas importam para argumentar sobre as forças psicológicas e os fatores espirituais que aproximam, unem, distanciam ou separam as pessoas e grupos. Assim se Simmel é um dos pioneiros sobre a formação da individualidade, dando conta dos dilemas da construção da subjetividade, trata das ações recíprocas dos indivíduos, que em sua liberdade de expressão, também contempla a cooperação e a solidariedade.

Neste dossiê, buscamos trazer estudos sobre as cidades ao mesmo tempo que acolhem o habitante em suas territorialidades públicas, concebendo práticas coletivas ou de valorização individual e coletiva, são lócus de estigmas e segmentações, de exclusões e injustiças sociais quanto aos "direitos à cidade" argumentados por Henri Lefebvre. Em todas crises sociais no mundo urbano, podemos, pois, perguntar sobre as formas de solidariedade que estetizam as relações humanas na vida urbana. Seguindo Simmel, ao tratar das formas de sociação, apontamos para a importância de pesquisas que tratam da articulação de grupos e redes na superação às crises e ameaças próprias do mundo contemporâneo.

No nível do Estado, as gestões públicas adotam estratégias políticas compartilhadas, bem como buscam, na solidariedade, mecanismos para enfrentamentos ("crisis facingment"). Sem dúvida vivemos em 2020, um ano extraordinário em sua complexidade por fatores pandêmicos em proporções mundiais. No Brasil, as ações estatais foram escassas para prevenir e combater o índice letal da doença. Nas margens da ineficiência estatal, as ações civis de solidariedade são inúmeras e colaboram na sustentabilidade das formas dignas de vida humana. Além desta crise, específica que nos motiva a reflexão, outras situações de redes de solidariedade, de troca e de reciprocidade, são geradas no interior das situações críticas da vida cotidiana dos citadinos.

Este dossiê contempla artigos no âmbito da pesquisa antropológica e sociológica sobre esses dramas da vida social, estudos que relatam e interpretam ações dos citadinos nas suas formas de resistência, de fazeres e saberes de solidariedade que revelam os esforços culturais, simbólicos, emocionais ou políticos de superação da anomia social e desestruturações político sociais.

O artigo de Erlan José Gatinho, João Plinio Ferreira de Quadros e Nivia Maria Vieira Costa, intitulado $O$ olhar invisível: visões e narrativas de populares em situação de rua e vulnerabilidade social nos tempos de pandemia da covid-19 em Bragança-PA, consiste em estudo realizado na cidade de Bragança, Pará, que pesquisou indivíduos em situação de rua para refletir sobre a vulnerabilidade social em tempos de pandemia da covid-19. O estudo acompanha a situação de alguns moradores de rua atendidos por coletivos, o que permitiu uma aproximação para conhecer a forma singular como vivenciam a crise pandêmica. 
Este artigo se apoia teoricamente em Velho (1973); Lefebvre (2011); Santos (2020), Bauman e Donskis (2016), mostrando a invisibilidade destes sujeitos na cidade e reflexões críticas acerca da pandemia de covid-19.

$\mathrm{Na}$ sequência trazemos o artigo de Otávio Amaral da Silva Corrêa, intitulado Solidarity through a network system: the case of Indian migrants in Marseille/ France. Ambientado na França, em uma cidade fortemente caracterizada pela presença de populações migrantes em diferentes conjunturas o autor, antropólogo brasileiro, se insere em um contexto étnico diverso. Desenvolve uma pesquisa etnográfica junto a migrantes indianos para considerar, no interior de suas vidas cotidianas, suas representações simbólicas e seu imaginário cultural. Para considerar este objetivo, aprecia as formas de sociabilidade, de reciprocidade, de ajuda e de solidariedade, seja no âmbito do contexto da cidade de Marselha, seja nos fluxos migratórios internacionais, buscando considerar as trajetórias e processos de enraizamento na realidade francesa.

O próximo artigo se intitula Praças comunitárias de sucata na "cidade Sol" - JequiéBA: lugar de brincadeira, preservação e aprendizagem social, de Marilete Calegari Cardoso e Ana Lúcia Santos Souza. O estudo se desenvolve na cidade de Jequié, no estado da Bahia, tendo por foco a qualificação dos espaços públicos. Com uma reflexão crítica sobre a negligência do estado para com os dispositivos públicos, as autoras trazem os resultados de sua pesquisa sobre a ação de citadinos na construção de praças comunitárias para fins lúdicos. Com base em entrevistas e observação, incluindo rico material fotográfico, revelam a ação solidária que atende a prática do brincar, do lazer e de sociabilidade lúdica na organização de um espaço público acessível a população geral para desenvolverem eventos comunitários, jogos e brincadeiras infantis, em "praças comunitárias específicas". Contextos que abrigam as ações de citadinos onde podem praticar "identidades comunitárias", evidenciando os equipamentos disponíveis que são oriundos de sucatas revitalizadas.

O artigo que segue, dos autores Francivaldo José da Conceição Mendes e Márcio Douglas do Amaral, com o título O lazer no cotidiano: práticas coletivas como resistência, traz uma revisão conceitual do conceito de lazer objetivando demonstrar "que em diferentes contextos espaciais vigoram variadas práticas que, a despeito de serem consideradas pouco importantes, constituem-se em conteúdos significativos da vida social urbana". (MENDES; AMARAL, 2020, p. 01). Esta revisitação conceitual nos motiva a refletir sobre a qualidade das práticas e formas de resistência que podemos reconhecer na noção de lazer, para além de ditames de racionalidade e normas de consumo. Conforme os autores "A reflexão aqui proposta parte de uma revisão bibliográfica combinada com reiteradas observações em campo que se deram em cidades da Amazônia e de outras regiões do Brasil. Em que pese a predominância da abstração do espaço urbano verificou-se que os sujeitos, nos diferentes tempos e espaços, mantêm uma sofisticada rede de interação e sociabilidade cuja materialidade remete a práticas espontâneas, não racionalizadas, notabilizando caminhos reais para uma cidade, um cotidiano, diferentes para e pelo lazer". (MENDES; AMARAL, 2020, p. $01)$.

Por fim, o artigo intitulado Territorialidades urbanas: a representação simbólica da cidade Andina na literatura peruana, de Flávio Reginaldo Pimentel e Márcia Aparecida da Silva Pimentel. A motivação dos autores não é tratar diretamente do tema do dossiê, mas podemos encontrar os laços de solidariedade e resistência nos diálogos dos personagens do livro Os rios profundos, de José María Arguedas de 1958, ao trazerem em suas narrativas os sentimentos mais profundos de reconhecimento ancestral nas territorialidades e no patrimônio cultural de pertença nativa. Os autores Pimentel e da Silva Pimentel (2020), tendo por foco uma correlação entre a literatura e a filosofia, se apoiam nos conceitos de "territorializaçãodesterritorialização-reterritorialização", definidas por Gilles Deleuze e Félix Guattari (1997), como suporte teórico para adentrar ao texto literário. Tais conceitos aparecem nos escritos 
desses autores, em $O$ Anti-Édipo (1972), e desdobrados, sobretudo, em Mil Platôs (1980) e $O$ que é a filosofia? (1991)." Ambientado na cidade de Cusco (Peru), o romance relata a trajetória de Ernesto, recém chegado neste contexto em companhia do seu pai, em que experimentam um jogo de alteridades de si no reencontro com rastros da cultura incaica na Cusco colonizada e moderna, sustentando uma lógica decolonial no jogo identitário híbrido e plural destes personagens. Para os autores Pimentel e da Silva Pimentel (2020, p. 14), o "espaço urbano de Cusco favorece um movimento rizomático das territorialidades, pois é nesse espaço ficcional que se encontram imbricados os diversos mundos antagônicos".

\section{Os organizadores}

\section{Dra. Cornelia Eckert}

Universidade Federal do Rio Grande do Sul, Porto Alegre, Brasil. Email: chicaeckert@gmail.com. Doutora em Antropologia Social pela Paris V, Sorbonne, França, 1992. Atua no Programa de Pós-Graduação em Antropologia Social pela UFRGS. Coordena o Núcleo de Antropologia Visual e o Banco de Imagens e Efeitos Visuais. https://www.ufrgs.br/biev/ Porto Alegre, RS, Brasil.

\section{Dr. Daniel dos Santos Fernandes}

Professor Convidado no Programa de Pós-Graduação em Estudos Antrópicos na Amazônia (PPGEAA), UFPA-Castanhal. E-mail: dsfernandes@ufpa.br. Doutor em Ciências Sociais/Antropologia, Vice-coordenador do Colaboratório de Interculturalidades Inclusão de Saberes e Inovação Social (COLINS/UFPA-Castanhal). 